Original Article Received/Accepted Dates 15.11.2021/28.12.2021

DOI: $10.52096 /$ jsrbs.7.14.18
Sosyal Araştırmalar ve Davranış Bilimleri Dergisi

ISSN:2149-178X

Volume: 7 Issue: 14 Year: 2021

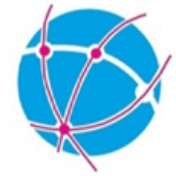

\title{
Perakendeci Bakış Açısı ile Omnichannel Yaklaşımı ve Tüketici: Bir Mobil Cihazlar Firması Örneği
}

\author{
Öğr. Gör. Berkay ÖZKAYA \\ Türk Hava Kurumu Üniversitesi \\ İzmir Havacılık Meslek Yüksekokulu \\ bozkaya@thk.edu.tr \\ 0000-0001-6238-866X
}

Doç. Dr. Keti VENTURA

Ege Üniversitesi

İktisadi ve İdari Bilimler Fakültesi

keti.ventura@ege.edu.tr

0000-0002-6422-0518

\section{Özet}

Çalışmanın amacı, mobil cihaz perakendecilerinin bütüncül kanal yaklaşımına bakış açılarını ve uyum düzeylerini anlamak ve yaklaşımın müşterilere ne gibi faydalar sunduğunu ortaya çıkarmaktır. Keşifsel nitelikte tasarlanmış olan çalışmada, nitel araştırma yöntemleri ve yarı yapılandırılmış mülakat tekniği uygulanmıştır. Yöntemin kullanılmasındaki amaç mobil cihazlar pazarında müşteriye sunulan faydaların keşifsel olarak ortaya koyulması olmuştur. Bu kapsamda yargısal örnekleme tekniği ile Türkiye'nin yerli akıllı telefon üreticisi olan bir firmadan bütüncül kanal yaklaşımı ve mobil cihazlar konularında bilgili kişileri ile görüşülmesi hedeflenmiştir. Buna bağlı olarak Akıllı Telefon, Mobil ve IOT Cihazlar Pazarlama ve Ürün Yöneticisi, E-Ticaret Uzmanı ve Perakende Pazarlama ve Müşteri Deneyimi Geliştirme Departmanlarından dört (4) kişi ile mülakat gerçekleştirilmiştir. Çalışmanın tek bir firma özelinde ve yargısal örnekleme tekniği ile belirlenen şahıslarla gerçekleştirilmiş olması ve örneklem evreninin büyük bir bölümünü kapsamıyor olması çalışmanın kısıtlarını oluşturmaktadır. Elde edilen bulgulara göre mobil cihazların öncelikli faydasının, müşterilerin bütüncül kanal entegrasyonunda diğer tüm pazarlarla da etkileşimi artırmak olduğu anlaşılmaktadır. Ayrıca firmaların müşteri merkezli davranması, zaman, mekân, azalan risk gibi birçok kriterin de müşterilere bütüncül kanal faydası sağladığı belirlenmiştir. Diğer taraftan 
bütüncül kanal altyapısının halen daha tam olarak yerleşmemiş olmasının müşterilerin her kanalda tek bir müşteri olarak algılanamaması sorununu ortaya çıkarmaktadır. Hem müşteri hem de işletme faydalarının en üst düzeye çıkarılabilmesi için bütüncül kanal altyapısının iyileştirilmesi gerektiği, bu durumun kazan kazan ilişkisinin daha kuvvetli bir şekilde gerçekleşmesine olanak sağlayacağı gözlenmektedir.

Jel Kodları: L81, M31, M10

Anahtar Kelimeler: Bütüncül kanal, perakende, mobil cihazlar, e-ticaret, tüketici

\title{
The Omnichannel Approach with a Retailer Outlook and Consumer: The Case of a Mobile Devices Firm
}

\begin{abstract}
The present study aims to explore the perspectives and adaptation levels of mobile device retailers towards omnichannel and to determine the benefits offered by the approach for the customers. The study adopts a explorative method, using qualitative research methods and semi-structured interview technique. This method has been used to unravel the benefits for the customer in mobile device market in a explorative approach. In this respect, we aimed to interview representatives with a certain degree of awareness about omnichannel and mobile devices from a smart phone manufacturer based in Turkey using purposive sampling method. As a result, interviews have been made with 4 people from the department of Smart Phone, Mobile and IOT Devices Marketing and Product Manager, E-Commerce Specialist and Retail Marketing and Customer Experience Development. The fact that the interviews have been made with people selected by purposive sampling method, included only one firm and thus has excluded a significant portion of the sampling, are the limitations of the study. Results reveal that the primary benefit of mobile devices is increasing the interaction between the customers of all other markets in terms of omnichannel integration. Furthermore, various factors such as customer-oriented behavior of firms, time, space and decreasing risk offer benefits for the customers. On the other hand, the fact that omnichannel infrastructure is not still well established causes a problem: the customers cannot be perceived as a single customer in each channel. It has been observed that omnichannel infrastructure has to be improved to maximize the benefits for the customers and firms, which will in turn, provide a win-win situation.
\end{abstract}

Jel Codes: L81, M31, M10

Keywords: Omnichannel, retail, mobile devices, e-commerce, consumer 


\section{Giriş}

Dünya genelinde, internet kullanıcısı olan nüfusun genel nüfus içerisindeki oranına bakıldığına internete girişin oransal olarak daimi artış gösterdiği gözlemlenmektedir. 2016 yılında 7.4 milyar olan dünya nüfusunda internet kullanıcısı oranı \%46 (3.4 milyar) iken, 2019 yılına gelindiğinde 7.53 milyarlık dünya nüfusunun \%51,2 (3.9 milyar)'sının internet kullanıcısı olduğu gözlemlenmektedir. Bununla birlikte 2016 yılı itibarıyla 1.6 trilyon dolar işlem hacmine sahip olan e-ticaret pazarı, 2019 yıl tahminlerine göre 3,5 trilyon dolarlık bir pazar büyüklüğüne erişecektir. Türkiye'de döviz kuru ve küresel boyutta yaşanan gelişmelerin etkileri dikkate alındığında büyüme oranlarında bir önceki yıla göre durağanlık göstermesi beklenmesine rağmen TL bazında \%42, dolar bazında \%7'lik bir büyümeye konu olmuştur (Dicle vd., 2017; Dicle vd., 2019). Bununla birlikte küresel perakende e-ticaret pazarında yıllara göre değişsim Grafik 1'de gösterildiği şekildedir (Chevalier, 2021).

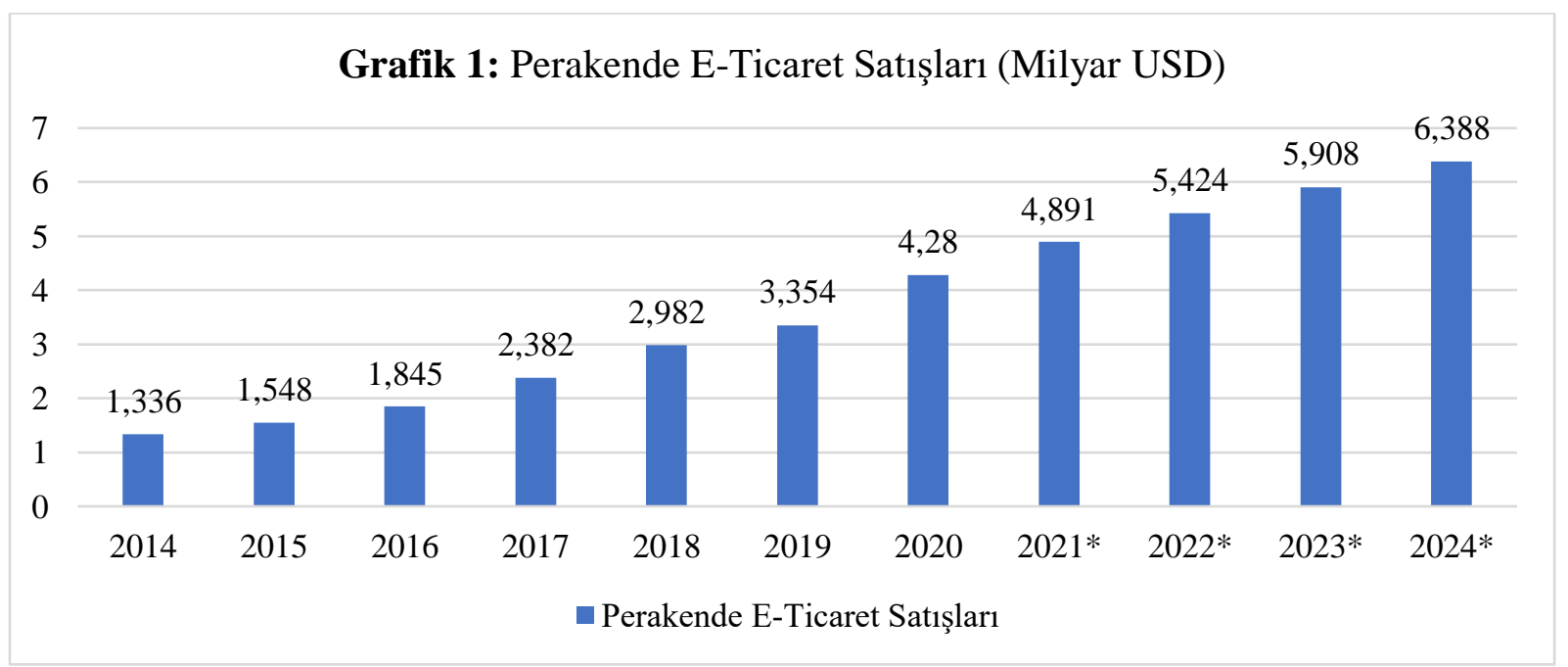

Kaynak: Chevalier, S. (2021). Retail e-commerce sales worldwide from 2014 to 2024.

Türkiye' de ise toplam e-ticaret içerisinde perakendenin payının \%64 olduğu, 2020 yılında e-ticaret hacminin \%66, e-ticaret sipariş sayısının ise \%68 arttığı gözlenmektedir (Ticaret Bakanlığ1, 2021). Mobil cihazların tüketiciye ticari faaliyetlerinde birçok kolaylık sağladığı dikkate alındığında özellikle perakende sektöründe bütüncül kanal deneyiminin önemi daha da artmaktadır. Web sitesi mobil ile uyumlu olmayan işletmelerin site ziyaretçilerinin \%61'i ticari faaliyetlerine mobil uyumlu rakip işletme siteleri üzerinden devam etmektedir. 3,5 milyarlık sosyal medya kullanıcısı olan dünya nüfusunun 2,8 milyarlık bölümü online alışveriş yapanlardan oluşmaktadır. Türkiye'de 
ise e-ticarette sırası ile giyim, elektronik, yemek siparişi, seyahat/konaklama ve kitap kategorilerinde alışveriş gerçekleştirilmektedir (Dicle vd., 2019). E-ticaretin seyretmekte olduğu yükseliş trendi dikkate alındığında mobil ticarete odaklanmak bir tercihten öte zorunluluk olarak değerlendirilmektedir.

Bütüncül kanal yaklaşımının günden güne önem kazanmasında tüketici davranışlarındaki değişimler, alım gücü, mobilite artışı gibi faktörler dikkat çekmektedir. Fiziksel mağazaları ziyaret eden kullanıcıların \%50 ila \%60 oranında değişen bir kesimi ürün karşılaştırmaları için de mobil cihazlarını kullanmaktadır. Ayrıca yine fiziksel mağaza ziyaretçilerinin yarısına yakınının mağazayı ürün ya da hizmet satın almak için değil, ürünü araştırmak ve kıyaslama yapmak maksadı ile ziyaret ettiği gözlemlenmektedir (Kang, 2018). Fakat bununla birlikte fiziksel mağazadan alışveriş yapanların oranı da yıllar içerisinde ciddi bir azalma ya da artış eğilimi göstermemektedir (Kazançoğlu vd., 2017). Bu durum ürünü görerek, temas ederek satın alma davranışı sergileyen müşterilere hitap eden fiziksel mağazalar ile çevrimiçi satın alma davranışı sergileyen müşterileri göz ardı etmeden tüm kanalları entegre etme gerekliliğini ortaya çıkartmaktadır. Göstergelerden anlaşıldığı üzere bütüncül kanalın artan önemi kavramı ve faydalarını kapsamlı şekilde anlamayı ihtiyaç haline getirmektedir. Buna göre konu çalışma mobil cihaz perakendecilerinin bütüncül kanal yaklaşımına bakış açılarını ve uyum düzeylerini anlamayı ve yaklaşımın müşterilere ne gibi faydalar sunduğunu ortaya çıkarmayı amaçlamaktadır.

\section{Bütüncül Kanal Yaklaşımı}

Söz konusu kanal stratejisi "omni” kavramı ile ilişkilendirilmektedir. Omni kavramı ise Latince kökenli bir kelime olup Türkçe'de her şey, hep, tüm, bütün gibi kelimelere karşılık gelmektedir. Öncül çalışmalarda, omni kavramının kanallar arasındaki farkın daha anlaşılır şekilde tanımlanmasına yardımcı olması için Türkçe karşılık olarak bütüncül kelimesi ile eşleştirildiği görülmektedir. Buradan hareketle uluslararası literatürde omnichannel olarak kullanılan kavramın Türkçe literatüre bütüncül kanal olarak yerleşmeye başladığı görülmektedir (Hüseyinoğlu, 2017).

Çevrimiçi satışların hızlı bir şekilde artış göstermesi, müşteri davranışlarının değişen doğası çoklu ve/veya çapraz kanalların yetersiz kalmasını ve bütüncül kanal yaklaşımının önem kazanmasına vesile olmuştur. Sayıca çok olan mevcut kanalların, müşteri temas noktalarındaki tecrübelerini 
artırmak ve performansa olumlu etki etmek amacı ile entegre edilerek servis edilmesi/kullanılması olarak açılanabilmektedir (Hüseyinoğlu, 2017). Gelişmiş bir yaklaşım olarak bütüncül kanal yaklaşımı müşterilerin ve markanın kanallar arasında ayrım gözetmeden davranış sergilemesini sağlamaktadır. Müşteriler arzu ettikleri hizmetleri ve/veya ürünleri fiziksel ya da çevrimiçi mağaza ayrımı farkı olmadan araştırma, inceleme, deneyimleme ve sipariş verme firsatını yakalamaktadır. Markalar da operasyonel süreçlerinin tamamında kanallar arası farkı ortadan kaldırarak tedarik ve temin tahsis etme esnekliğine erişmektedir. Mağaza, telefon, bilgisayar, katalog ve e-ticaret mağazalarının entegrasyonu ile birlikte müşteriler markanın sunmuş olduğu ürün evtanterine ve fiyatlandırmasına kanal farkı olmadan erişim sağlamaktadır. Müşteri, markayla olan iletişim ve ticari girişim davranışlarının temin ve iade gibi süreçlerde kanal farkı göz etmeksizin davranış gösterebilmektedir. Müşteriler böylelikle, karşısındaki markaya ilişkin farklı kanallar yerine tek bir marka görmektedir. Markalar da kullanıcılarını stratejik ve operasyonel süreçlerde tek bir müşteri olarak görmekte ve buna göre davranmaktadır (Hübner vd., 2016; Dicle vd., 2017; Beck, Rygl, 2015).

Bütüncül kanal ile birlikte fiziksel temas noktaları, geleneksel dijital temas noktaları ve gelişmekte olan dijital temas noktaları ilham yaratılması, seçim ve onay, satın alma ve ödeme ve tekrar gereklilikler için kategorik olarak ele alınmaktadır. Buna göre farklı temas noktaları konu işlem basamaklarına göre Tablo 1'deki gibi tanımlanabilmektedir;

Tablo 1: İşlem Basamaklarında Temas Noktaları

\begin{tabular}{|c|c|c|c|}
\hline $\begin{array}{c}\text { İşlem } \\
\text { Basamakları / } \\
\text { Temas Noktaları }\end{array}$ & $\begin{array}{c}\text { Fiziksel Temas } \\
\text { Noktaları }\end{array}$ & $\begin{array}{l}\text { Geleneksel Dijital } \\
\text { Temas Noktaları }\end{array}$ & $\begin{array}{c}\text { Gelişmekte Olan Dijital Temas } \\
\text { Noktaları }\end{array}$ \\
\hline İlham Yaratma & $\begin{array}{l}\text { Önceki deneyimler, TV, } \\
\text { radyo, aile ve yakın çevre }\end{array}$ & $\begin{array}{c}\text { Kullanıcı yorumları, } \\
\text { bloglar, Youtube, } \\
\text { Pinterest }\end{array}$ & Kitle kaynak teklifleri \\
\hline $\begin{array}{l}\text { Seçim ve } \\
\text { Onaylama }\end{array}$ & $\begin{array}{l}\text { Mağaza içi etkileşim ve } \\
\text { gösterimler, e-posta } \\
\text { gönderimleri, haftalık }\end{array}$ & $\begin{array}{l}\text { Perakendecilere ait } \\
\text { web siteleri, }\end{array}$ & $\begin{array}{l}\text { Kişiselleştirilmiş e-postalar, QR } \\
\text { kod, mağaza içi kiosklar, aboneler } \\
\text { için teslimat kutuları, dijital raflar, }\end{array}$ \\
\hline
\end{tabular}




\begin{tabular}{|c|c|c|c|}
\hline & $\begin{array}{l}\text { önerge bildirimleri, } \\
\text { ürünlerin paketlenmesi }\end{array}$ & $\begin{array}{l}\text { imalatçılara ait web } \\
\text { siteleri }\end{array}$ & $\begin{array}{c}\text { imalatçılara ait mobil uygulamalar, } \\
\text { perakende mobil uygulamaları }\end{array}$ \\
\hline $\begin{array}{l}\text { Satın Alma ve } \\
\text { Ödeme }\end{array}$ & $\begin{array}{c}\text { Mağaza içinde } \\
\text { kullanılabilir kupon ve } \\
\text { anlık indirimler, yardım } \\
\text { alarak satın alma işlemleri }\end{array}$ & & $\begin{array}{l}\text { Mobil ödeme, uyarlanabilir } \\
\text { fiyatlandırma, içeriğe dayalı mobil } \\
\text { kuponlar ve anlık bildirimler, } \\
\text { hareket halinde ödeme, talebe uygun } \\
\text { yerel teslimat modelleri }\end{array}$ \\
\hline $\begin{array}{c}\text { Tekrar } \\
\text { Gereklilikleri }\end{array}$ & $\begin{array}{l}\text { Müşteri ilişkileri, sadakat } \\
\text { programları, arkadaşlara } \\
\text { ve aileye tavsiye }\end{array}$ & & $\begin{array}{l}\text { Blog ve sosyal medya gönderileri, } \\
\text { düzenli abonelikler, mobil sadakat, } \\
\text { çevrimiçi ürün değerlendirme }\end{array}$ \\
\hline
\end{tabular}

Kaynak: Dicle, E., Avcı, Y. E., Gülyurt, L. (Ed.). (2019). E-Ticaretin Gelişimi, Sınırların Aşılması ve Yeni Normlar 2019. Deloitte Digital ve TÜSİAD, s., 101.

\subsection{Bütüncül Kanala Geçiş Süreci}

Çok sayıda kanalın müşterilerle etkileşim noktasında daha entegre bir yapıda faaliyet göstermesi olarak açıklanan bütüncül kanal yaklaşımında çoklu kanalın genişlemiş yapısına ek olarak müşteriye ve markaya ilave kazanımlar da sağlamaktadır. Müşterilerin kanallar arasında maruz kalmış olduğu sınırları ortadan kaldıran bütüncül yaklaşım, kapsamı genişleterek marka iletişimi kuvvetlendirmektedir (Kazançoğlu vd., 2017). Tablo 2 her iki kanal arasındaki temel farklılıkları yaklaşımların yönetim süreçleri açısından ortaya koymaktadır.

Tablo 2: Çoklu Kanal ile Bütünsel Kanal Yaklaşımın Farklılıkları

\begin{tabular}{c|c|c}
\hline Kanalın Odak Noktası & Yalnızca interaktivite & Hem interaktivite hem kitlesel iletişim \\
Kanal Kapsamı & $\begin{array}{c}\text { Fiziki ve fiziki olmayan mağaza, } \\
\text { doğrudan iletişim (perakende } \\
\text { kanallar) }\end{array}$ & $\begin{array}{c}\text { Fiziki ve fiziki olmayan mağaza, } \\
\text { doğrudan iletişim (perakende } \\
\text { kanallar); akıllı telefon, tablet, } \\
\text { uygulamalar (mobil kanallar); TV, } \\
\text { radyo vb. (kitle iletişim kanalları) }\end{array}$ \\
\end{tabular}




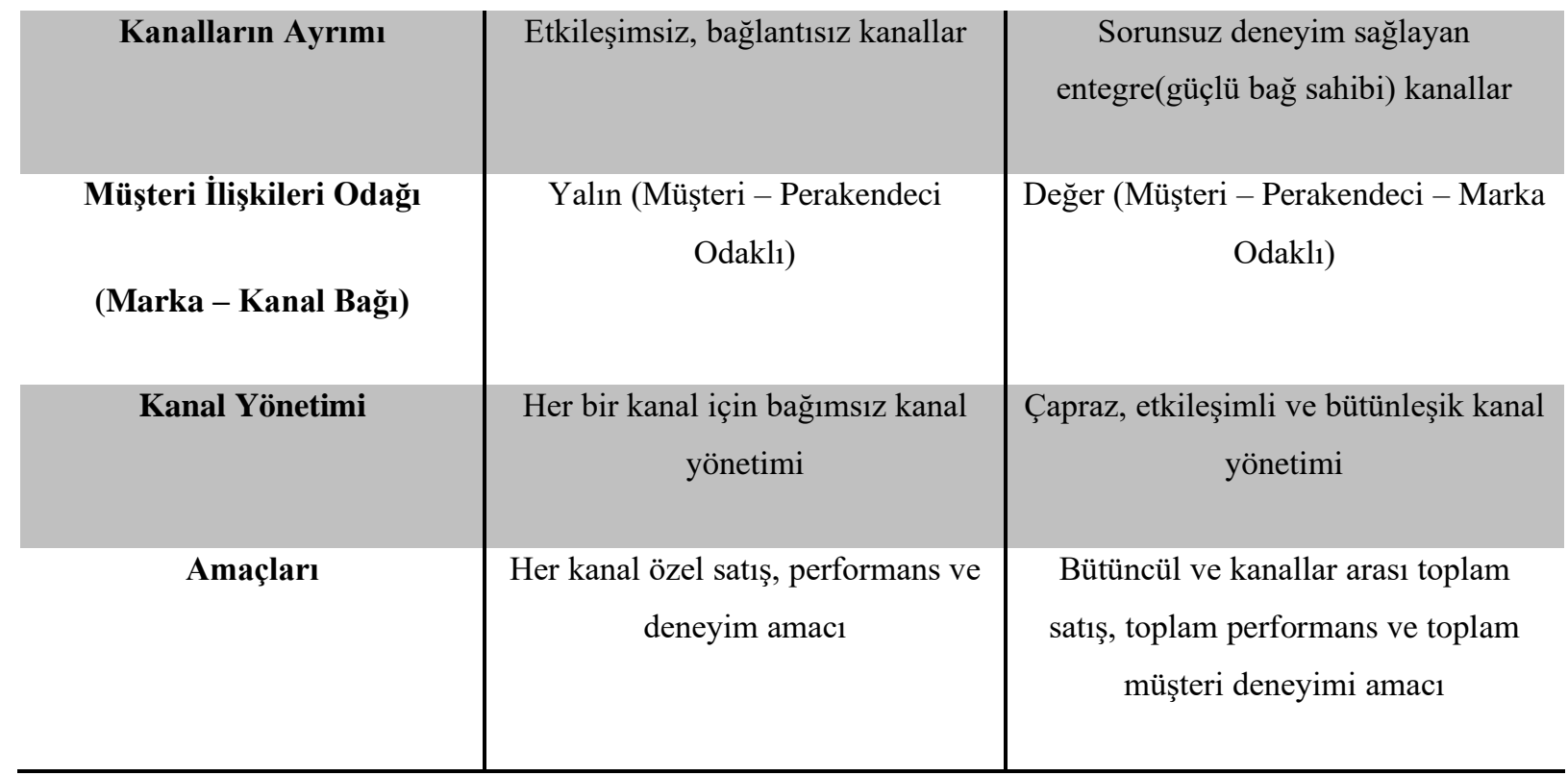

Kaynak: Verhoef, P. C.,Kannan, P. K., Inman, J. J. (2015). From multi-channel retailing to omni-channel retailing introduction to the special issue on multi-channel retailing. Journal of Retailing, 91, (2), 176.

Çoklu kanal ile bütüncül kanal arasındaki farklılıklar, süreç içerisinde hızla gelişen bilişim teknolojisi, bilgisayar sanayi ve akıllı sistemlerle paralellik gösteren tüketici davranışları olmuştur. Hıza ve çabuk erişime adaptasyon, işletmelerin de müşteri iletişiminde aynı kanalları kullanmasını zorunluluk haline getirmiştir. Bütüncül kanal yaklaşımı ile birlikte müşteriler kanallar arasında gezinirken kaybolmak yerine, bıraktığı izlere çabuk erişim istemektedir. Ayrıca yine müşteriler çoklu kanalda birbirinden bağımsız olan marka kanallarını, bütüncül yaklaşımda tek bir ağ içerisinde yer alan farklı platformlar olarak görmektedir.

\subsection{Tüketim Alışveriş Eğilimleri}

Bütüncül kanal yaklaşımının dağıtım stratejilerine de yeni bakış açıları kazandırdığı gözlenmektedir. Fiziksel ve çevrimiçi mağazanın, posta, sms, uygulamalar, bilgisayar gibi kanalların entegre olması ile birlikte internette araştırıp mağazadan alma, mağazada beğenip internetten alma, uygulamadan araştırıp bilgisayardan alma, bilgisayarda rezerve edip mağazadan alma gibi çeşitli kombine kanal deneyim seçenekleri ortaya çıkmıştır (Hübner vd., 2016).

Webrooming ve showrooming kavramları ise bütüncül kanal yaklaşımın hâkim uygulama yaklaşımları olması ile birlikte tüketiciler tarafından ağırlıklı olarak kullanılan/öne çıkan alışveriş eğilimleri olarak açıklanmaktadır. Söz konusu kavramlardan showrooming Kotler tarafından, 
araştırmanın fiziksel mağazadan yapılıp ürün/hizmetin internetten alınması olarak açıklanmaktadır. Webrooming ise; araştırmanın internetten yapılıp ürün/hizmetin fiziksel mağazadan alınması olarak açıklanmaktadır (Kotler, 2018). Kanallardaki kesintisiz bağlantı müşterilerin arama, kıyaslama ve satın alma süreçlerinde hâkimiyetlerini artırmıştır. Bu durum kontrol edilmesi zor hatta neredeyse imkânsız bir bütüncül kanal sistemi yaratmaktadır. Bu nedenle müşteri temas noktalarını artırmak ve reklam amaçlı mesajları mobil uygulamalarla etkileşimli hale getirmek önem arz etmektedir (Verhoef, 2015).

Fiziksel mağazaların yoğunluğu, seçeneklerin çokluğu dikkate alındığında müşterin arzu ettiği ürüne ulaşması zor olmakta, kafa karışıklığı markanın gözden kaybolmasına ve arzu edildiği gibi fark edilmemesine yol açmaktadır. Benzer şekilde fiziksel temas olmaksızın satın alma davranışı göstermekten kaçınan tüketici kitlesi de ulaşılabilir ve zaman kısıtı gibi sorunlarından ötürü markaya ulaşamamakta, arzu ettiği faydayı istediği konumda yakalayamamaktadır. SoLoMo olarak kısaltılan "işbirliği ve paylaşma özelliği (sosyal)”, "konuma dayalı işlevler (lokasyon)” ve "hareket halinde kullanım özellikleri (mobil)" olarak açıklanan kavram, müşterilerin üç bileşen vesilesinde rahatlıkla izlenmesini ve tanınmasını sağlamaktadır. Bu noktada önemli uygulama faaliyeti ise webrooming ile showrooming alışveriş eğilimlerinin entegre edilmesidir. Sanal uygulamalar ile fiziksel mağazada bulunan müşteri ile temasa geçilmesi, sanal mağazaya erişebilir durumda olan müşterinin işe fiziksel mağaza koşullarını elde etmişçesine davranış sergilemesi sağlanmalıdır (Kotler vd., 2018).

\subsection{Tüketici Bakış Açısı ve Faydaları}

Perakende tüketimde fiziksel mağazalar, mobil uygulamalar, kataloglar, satış bültenleri, sms, eposta, destek hattı, paylaşım siteleri, çevrimiçi mağazalar markalar için müşteri ile temasta kanal sayısını nitelemektedir. $\mathrm{Bu}$ kanalların nicel olarak fazlalığı çoklu kanal yaklaşımı olarak açıklanırken, tüm bu kanalların entegre biçimde müşteriyi merkeze alarak hizmet vermesi bütüncül bir yaklaşımı ifade etmektedir. Çoklu kanal yaklaşımında müşteriyi her kanalda ayrı ayrı yakalamak gerekirken, bütüncül yaklaşımda bu durum herhangi bir kanal üzerinden tek seferde gerçekleşebilmektedir. Bu noktada işletmeleri çoklu kanal uygulamalarını entegre etmeye iten ve tek bir kanalda her defasında yeniden var olmak yerine her kanalda tek bir müşteri olarak var olma kaygısı bütüncül kanal yaklaşımın kuvvetlenmesine sebep olmuştur (Aydın vd., 2017). 
Konuya ilişkin gerçekleştirilen çalışmalar dikkate alındığında bütüncül kanal yaklaşımının farklı bakış açıları ile tartışıldığı görülmektedir. Çağdaş tüketici kimliğinin fiziksel mağaza etkinlikleri, çevrimiçi mağaza yapıları ve mobil taramaları birbirine birleştiren gerçek ve dijital etkinliğin karışımını talep ettikleri varsayımı ile Peltola vd. (2015) gerçekleştirdikleri çalışmada yedi adet Fin perakendeci ile mülakat yapmıştır. Değişen tüketici davranışlarının sadece hizmetleri değil, organizasyon yapısını ve tedarik zincirini de etkilediği sonucuna ulaşılmıştır. Ayrıca müşteri deneyimi başarısının kesintisiz müşteri temas noktaları ile organizasyon kültürü, fiyatlandırma, operasyon ve iletişim birliğinde yattığı ifade edilmiştir.

İngiltere kadın giyim ve Almanya teçhizat pazarlarında yapılan bir çalışmada perakendecilerin kanalları üzerindeki varlığın hem mağaza satışlarını hem de toplam satışları arttırdığı sonucuna ulaşılmıştır. Yine mağaza dışı satışların \%95'inin mağaza satışlarını da arttırdığı, haftada en az 1 kez çevrimiçi alışveriş yapan bireylerin çevrimiçi kanalları daha az kullananlara göre alışveriş yapma ihtimallerinin \%30 daha yüksek olduğu gözlenmiştir. Ayrıca ilk etapta çevrimiçi araştırması sonra satın alması yapılan ürünlerin, direkt mağaza üzerinden alınan ürünlere göre ürün değeri bakımından \%55 daha yüksek olduğu belirlenmiştir (Giddes vd., 2014).

Yine aynı çalışmada (Giddes vd., 2014) tüketicilerin bütüncül kanal faydaları üç ana başlık altında ifade edilmiş̧ir. Bunlar; bilgiye kolay erişim, seçim seçenek ve hürriyet genişliği, zaman ve satın alma açısından kolaylık olarak ifade edilmiştir. Ayrıca bütüncül kanalın pazarı yeniden şekillendirip genişlettiği belirtilmiş olup, çevrimiçi alışveriş yapan tüketicilerin yaklaşık olarak $\% 25$ 'lik diliminin mevcut satın almalarını yerel mağazalardan yapamayacağını ifade etmiştir. Bununla birlikte alışverişlerin \%63'ünün birden fazla kanal üzerinden gerçekleştiği, her üç tüketiciden birinin son satın alımlarından birden fazla kanal kullandığı gözlenmiştir.

Cao ve $\mathrm{Li}$ (2015) tarafından gerçekleştirilen çalışmada ABD'de 71 perakende firması incelenmiştir. Buna göre bütüncül kanalı kullanan firmaların tek bir kanala yoğunlaşan firmalardan daha fazla fayda sağladığı, marka bilinirliğini artırdığı için müş̧terilerin yeni kanaldan satın alma riskini azalttığı gözlenmiştir.

Haziran 2015 ile Ağustos 2016 arasinda 14 ay süren ve 46.000 tüketicinin dâhil edildiği araştırmaya göre bütüncül kanal müşsterilerinin işletmeler açısından daha değerli olduğu sonucuna 
ulaşılmıştır. Çalışmada bütüncül kanal müşterilerinin yalnızca mağaza müşterilerine göre $\% 4$, tek kanal müşterilerine göre ise \%10 daha fazla harcama yaptıkları sonucuna ulaşılmıştır. Ayrıca kullanılan her ek kanalda tüketicilerin daha da fazla harcama yaptıkları gözlenmiştir. Dörtten fazla kanal kullanan müşterilerin, tek bir kanal kullananlara kıyasla mağazalarda ortalama olarak \%9 daha fazla harcama yaptığı anlaşılmaktadır (Sopadjieva vd., 2017).

Fiziksel mağazaların perakende hedefi olarak talep yaratma ve operasyonel verimlilikte fayda sağlayıp sağlamadığının araştırıldığı çalışmada (Bell vd., 2017) fiziksel mağazaların genel ve çevrimiçi kanallardaki talebi arttırdığı, ortalama olarak daha yüksek hizmet maliyetine sahip müşterileri çekerek diğer kanallarda operasyonel yayılımı sağladığı, geri dönüşleri azaltarak operasyonel verimliliği arttırdığı ve firma ürünlerine en fazla ihtiyaç duyan müşterilerle ilişkileri kurarak talebi ve operasyonel faydayı arttırdığ gözlenmektedir. Bununla birlikte kanal farkındalığını ve marka bilinirliğini de arttırdığı anlaşılmaktadır.

İletişim merkezleri bağlamında faydaların ve zorlukların ele alındığı çalışmada (Picek vd., 2018) iletişim merkezlerinin bütüncül kanaldaki yerine ilişkin etkileşim, bilgi, veri, teknoloji, temsilci, müşteri, maliyet, kanallar ve organizasyon başlıkları ile gruplandırılan 30'ya yakın fayda tanımlanmıştır.

Zhang ve Shi (2018)'in gerçekleştirdiği çalışmada bütüncül kanal yaklaşımı ön siparişler ve iade politikaları itibarı ile tüketici bakış açısını ele almaktadır. Çalışma kapsamında elde edilen bulgulara göre iadelerin nispeten düşük olduğu ve fiyat eşiği belirlemenin fayda sağladığı anlaşılmaktadır. Ayrıca bütüncül kanal yaklaşımı talep güncellemeleri ile birlikte daha fazla tüketicide tatmin yaratabilmekte ve daha yüksek tüketici refahı sağlamaktadır.

Perakendeciler tarafindan kullanılan çoklu kanallar aracılığıyla müşteri yönetimi firsatlarının belirlenmesi, müşteri yönetiminde yöntemlerin ilişkilerinin saptanması, karşılıklı bağımlılığın değerlendirilmesi ve bütüncül kanal müşteri yönetimi için öneri geliştirmesi amaçlanmıştır (Wollenberg vd., 2019). Keşif amaçlı gerçekleştirilmiş olup bu kapsamda 25 adet bütüncül kanallı perakendeci ile yüz yüze görüşmeler gerçekleştirilmiştir.Bulgular, perakendecilerin müşterileri mağazaya yönlendirmek, belirli operasyonel işlemlere öncelik vermek ve ürün iadelerini önlemek için ürün mevcudiyeti kontrollerini kullanmasını içermektedir. Doğru şekilde yürütüldüğü 
takdirde, bütüncül kanal müşteri yönetiminin yalnızca perakendeciler için farklılaşma ve çapraz satış potansiyeline neden olmakla kalmayıp, aynı zamanda müşteriler için ek fayda sağlayacağı da gözlenmiştir.

Barwitz ve Mass (2019)'ın çalışmasında çoklu katkı sağlanması amacı ile odak gruplarla, uzmanlarla ve motorlu sigorta müşterileri ile mülakat gerçekleştirilmiş olup, müşterilerin etkileşim seçimlerinin altında yatan ve açık nedenler araştırılmıştır. Elde edilen sonuçlara göre müşterilerin etkileşimde faydacı, hedonik, maliyet minimizasyonu ve ilişkisel olarak ifade edilen 4 adet kullanım değeri tanımladığı ortaya çıkmıştır. Ayrıca müşterilerin gözlemlenebilir etkileşim davranışlarına dayanan baskın çabaları itibarıyla bölümlere ayrılması önerilmiştir.

Berman ve Thelen (2019)'in gerçekleştirdiği çalışmada çoklu kanal ile bütüncül kanal arasındaki farklılıkların analizi, bütüncül kanalın avantajları ve bütüncül kanala en başarılı entegrasyonun nasıl olacağı olguları ele alınmıştır. Çalışma literatür çalışmalar, danışmanlık firma araştırmaları ve bütüncül kanal perakendecilerinin vaka çalışmaları incelenerek gerçekleştirilmektedir. İki kanal stratejileri arasındaki farklar ise; firmaların mevcut konum belirlemesi, sonraki seviyeye geçme noktasındaki stratejik boşlukları görmesi ve geçişte uyum eylemlerinin geliştirilmesi ile mümkün olacağı gözlenmiştir.

Shi vd. (2020) tarafindan gerçekleştirilen çalışmada öncelikle bütüncül kanal müşteri deneyimini kavramsallaştırmak ve bir anket aracı geliştirmek için karma yöntem yaklaşımı benimsenmiştir. Çalışmada algılanan uyumluluk ve algılanan risk, bütüncül kanal deneyimi ile alışveriş niyeti arasındaki anahtar bağlantı olarak kurulmuş olup nomolojik bir model geliştirmek için inovasyon yayılım teorisi kullanılmıştır.Buna göre algılanan risk ve algılanan uyumluluk olgularının bütüncül kanal alışveriş niyeti üzerinde etkili olduğu gözlenmiştir.

Zenner'e göre bütüncül kanalın teknolojik uygulamaları itibarıyla müşteriye sağladığı faydalar 3 başlık altında sınıflandırılmaktadır. Mağaza bulma ve envanter sorgulama avantajı müşterilerin çevrimiçi ağlar üzerinden konumlarına göre mağaza bilgisi paylaşımını ve mağazalardaki envanter durumlarını bildirerek zaman ve seyahat konularında tasarruf sağlamaktadır. Satış uygulamaları ve ekranlar aracılığıyla mağaza içi bilgilendirme ve sonsuz koridor avantajı sağlanmakta olup, sınırsız ürün seçimi, kolay erişimli ek bilgi ve mağazalarda kolay ürün seçimi firsatı sağlamaktadır. 
Fiziksel mağazalarda ise gün, saat seçimi ile stok bilgisi dâhilinde nakliye ve satın alma kararına ilişkin tercihli seçenek faydası sunmaktadır.

Tablo 3: Bütüncül Kanal Tüketici Bakış Açısı ve Faydaları

Farklı zamanlarda ve farklı kanallarda ürünü inceleme, sepete ekleme ve satın alma isteği

Alışveriş deneyiminin farklı kanallar üzerinden süreklilik sağlaması beklentisi

Tüketici değer beklentisinin tüm kanallarda eşit ve kümülatif olması isteği

İletişim kanalları arasında kesintisiz, sürdürülebilen bir alışveriş yapma beklentisi

Satış elemanı baskısının ortadan kaldırma isteği

Alışveriş sürecinde kontrolü ele geçirme isteği

Ürün ve hizmet çeşitliliğinden her kanalda, fiyat tutarlılığı ile faydalanma isteği

İndirim, ürün iade, satış ve sonrası destek gibi hizmetlerin her kanalda eşit olması beklentisi

Kaynak: Aydın, H., Kazançoğlu, İ. (2017). Çoklu kanal stratejisinden bütüncül kanal stratejisine geçişin tüketiciler tarafından kabulü. Mustafa Kemal Üniversitesi Sosyal Bilimler Enstitüsü Dergisi, 14, 59-60.

Farklı bakış açıları ile ele alınan bütüncül kanal yaklaşımında elde edilen sonuçlar dikkate alındığında doğru uygulamalarla birlikte satışları artırdığı, marka imajına katkı sağladığı, trafiği olumlu etkilediği anlaşılmaktadır. Bununla birlikte tüketicilere çeşitli fayda sağlayan bütüncül kanal yaklaşımı tüketiciler tarafından arzu etmekte ve hızlıca benimsenmektedir. Bu duruma sebep olan bakış açılarına ise Tablo 3 'te yer almaktadır.

\section{Mobil Cihazlar ve E-Ticaret}

Mobil kelimesi dilimize Fransızca "mobile" kelimesinden kazandırılmış olup, dilimizde hareketli/taşınabilir sıfatına karşılık gelmektedir (TDK, 2019). Mobil cihazlar ise taşınabilir, sürekli bağl1, kişisel ve küçük olma özellikleri ile (Sundet, 2007) tanımlanan dizüstü bilgisayar, masaüstü bilgisayar, akıllı telefon, tablet, akıllı saat, e-okuyucu vb. birçok gruba ayrılmaktadır (Deloitte,2017). 20. YY'ın son çeyreği ile meydana gelen teknolojik gelişmeler cep telefonunu ortaya çıkartmıştır. İlk dönemlerinde yalnızca sesli iletişim aracı olarak kullanılan cihaz, farklı 
birçok içeriği bünyesine dahil etmeye başlaması ile birlikte kişisel bir mobil cihaz haline gelmiş̧tir. 21. YY'ın hızla gelişen erişim/internet alt yapısı bireylerin bilgi edinme merkezini kitle iletişim araçlarından mobil cihazlara yönlendirmeye başlamıştır. Bu dönüşüm mobil cihazları yeni çağın başrol oyuncularından biri haline getirmiş̧tir (Kuyucu, 2017).

Birbiri ile direkt olarak ilişkide olan internet erişimi ve mobil cihaz tüketimi, konu eğilimin ne kadar büyük ve devamlı bir artış içerisinde olduğunu göstermektedir. 2005 yılında dünya nüfusunun yalnızca \%16,8'i internet erişimine sahipken, 2019 yılına geldiğimizde bu oran \%53,6'ya çıkmıştır. Bu oran aynı zamanda 2018 yılına göre \%5,3’lük bir büyümeyi ifade etmektedir. Mobil cihazların önemini gözler önüne seren bir başka değişim ise 2005 yılından 2019'a kadar geçen sürede sabit telefon abonelikleri sürekli olarak azalma eğilimi göstermekte olup, toplamda yaklaşık \%25 küçülmeye konu olmuştur. Diğer taraftan ise 2005-2019 y1llar arasında mobil hücresel telefon aboneliği yaklaşık olarak 3 kat artarken, mobil geniş bant aboneliğinde (3G, 4G vb.) 2007 yılından 2019 yılına kadar geçen sürede yaklaşık olarak 80 kat artış olduğu izlenmektedir.Bununla birlikte dünya nüfusunun tamamına yakını (\%97) bir mobil hücresel sinyale erişebilir bir noktada yaşamaktadır. Benzer şekilde dünya nüfusunun \%82'si LTE ya da daha yüksek bir mobil geniş bant sinyaline erişebilmekte ve \%11'i de $3 \mathrm{G}$ erişime sahip konumdadır (International Telecommunication Union Publications, 2019).

Türkiye'de mobil kullanıcılara ilişkin gerçekleştirilen çalışmada ise katılımcıların \%90'ının akıllı telefonlara, \%76'sının mobil bilgisayarlara erişiminin olduğu anlaşılmaktadır. Ayrıca mobil bir ağa bağlı herhangi bir akıllı cihaz ile yapılan işlemler incelendiğinde kullanıcıların sosyal medya ve banka hesabı kontrolü, arama motoru kullanma, haber okuma, alışveriş sitelerine göz atma, online satın alma, oyun oynama, film dizi izleme ve canlı TV izleme aktivitelerini gerçekleştirdiği ve aktivitelerin canlı TV izlemek dışında tamamında cep telefonu kullandığ 1 gözlenmektedir. Bununla birlikte gelir seviyesi fark etmeksizin katılımcıların \%58'inin cep telefonlarını son iki yıl içerisinde (2018 ve 2019) satın aldıkları anlaşılmaktadır. Ayrıca akıllı telefon satın alımlarının \%54'ü mağazadan gerçekleşmekte iken, \%21'i online kanallardan temin edilmektedir (DeLoitte, 2019).

Türkiye'de yetişkin bireylerin yaklaşık olarak \%77'si akı1lı telefon kullanmaktadır. Günümüzdeki ürün ve hizmet kategorisi göz etmeksizin ziyaretçi trafiği büyük çoğunlukla mobil cihazlar 
tarafından sağlanmaktadır. Özellikle online perakende alanında tüketici ziyaretlerinin \%70'den fazlası, ciroların ise \%60’tan fazlası mobil kanallar üzerinden gelmektedir (Dicle vd., 2019).

\section{Uygulama}

\subsection{Araştırma Amacı ve Kapsamı}

$\mathrm{Bu}$ araştırmanın amacı, mobil cihaz perakendecilerinin bütüncül kanal yaklaşımına bakış açılarını ve uyumluluk durumlarını anlamak ve yaklaşımın müşterilere ne gibi faydalar sunduğunu ortaya çıkarmaktır.Literatürde omnichannel yaklaşımı trend bir çalışma konusu olmakla birlikte, Türkçe alanyazında örneklerine sıklıkla rastlanan bir çalışma konusu olmadığı görülmektedir. Yakın dönem çalışmaları; gıda perakende (Hüseyinoğlu, 2017), tüketici kabulü (Aydın vd., 2017), lojistik faaliyetlere ilişkin zorluklar ve engeller (Kazançoğlu vd., 2017), değişen alışveriş alışkanlıkları (Marangoz, Aydın, 2017), tüketici algısı (Börühan vd., 2017) konuların literatüre katkı sağlamıştır. Bununla birlikte Türkiye'de e-ticaret eğiliminin en yüksek olduğu alanlardan mobil cihazlar pazarı ele alınmamış ve alanda ürün sunucusu pozisyonundaki işletme bakış açısından müşteri faydaları değerlendirilmemiştir. Buna bağlı olarak uygulama alanı ve örneklemi araştırmanın orijinalliğini ifade etmekte olup, perakendeci bakış açısı ile müşterileri faydalarının keşfedilmesi amaçlanmaktadır. Bu bağlamda perakendeci bakış açısı ile mobil cihazlar pazarında tüketicilerin elde ettiği faydaların tartışılmadığı görülmektedir. Araştırma, Türkiye mobil cihaz pazarında yerli üretim yapan ve bütüncül kanal yaklaşımını benimseyen perakendeciler içerisinden ulaşılabilen ve görüşmeyi kabul eden işletmeler ile sınırlıdır. Vaka analizi ve kalitatif araştırma yöntemi ile gerçekleştirilen çalışmada araştırma amaç ve kapsamı dahilinde katılımcılarla yüz yüze görüşmeler yapılmış ve elde edilen cevaplar yorumlanmıştır. Araştırma soruları aşağıda belirtildiği şekildedir;

- Bütüncül kanal yaklaşımına bakış açısı nedir?

- Bütüncül kanal yaklaşımına uyumluluk ne durumdadır?

- Bütüncül kanal yaklaşımının mobil cihazlar pazarında müşteriye sağladığı faydalar nelerdir?

Belirtilen araştırma sorularını tanımlayıcı, daha detaylı görüşme/mülakat soruları hazırlanmış olup gerçekleştirilen görüşmeler üç araştırma sorusuna yanıt bulacak şekilde tasarlanmıştır. 


\subsection{Araştırma Yöntemi}

Nitel araştırmalar sahışların duyguları, tecrübeleri, algıları, anlayışları ve fikirleri ile temellendirilen özellikte bir araştırma yöntemidir. Gözlem, görüşme ve doküman analizlerinin bütüncül bir yaklaşım ile yapıldığı, ele alınan konuyu keşfetme ve anlamlı bağlantılar ortaya çıkartma amacı ile metinlerin ve görüşlerin analiz edilerek yorumlandığı yöntemdir (Keegan, 2009).

Bu çalışmada,keşifsel nitelikte tasarlanan nitel araştırma yöntemlerinden vaka analizi yöntemi uygulanmıştır. Vaka analizi; seçilen olayın, sürecin ya da olgunun bütünlüğü ve birliği dâhilinde, derinlemesine araştırmayı, seçilenin kendi doğal ortamında ve bağlamında incelenmesini, tüm karmaşık süreçleri de dikkate alarak mümkün kılmaktadır. Derinlemesine irdelemeler yapmak, katılımcılardan elde edilen görüş ve bakış açıları arasındaki benzerlik ve farklılıkları yakından anlamak ve aktarmak, bu hususta oldukça anlamlı ve fazla bilgi sunmak vaka analizi şeklinde ifade edilmektedir (Yin, 2002; Punch, 2014). Bahse konu özellikteki çalışmalarda 3 ila 4 kadar katılımcı ile çalışma yapılabilmekte ve katılımcılara araştırma amaç ve kapsamı dahilinde sorular yönlendirilerek derinlemesine bilgi edinilmesi hedeflenmektedir (Ritchie, Lewis, 2003). Bu çalışma bahse konu tüm hususlar ile ele alınmış ve genelleme yapacak sonuçlar ileri sürmemiştir. Elde edilen bulgular, yalnızca vaka kapsamında irdelenmiştir.

\section{3.Örneklem Seçimi}

Araştırmada, analiz kapsamında vaka mobil cihazlar olarak seçilmiştir. Türkiye'de e-ticaret kullanıcıları sırası ile en çok giyim, elektronik ve yemek siparişi kategorilerinde işlem gerçekleştirmekte olup, elektronik kategorisinde birinci sırada \%51,97 ile telefon aksesuarları, ikinci sırada \%50,28 ile telefonlar, üçüncü sırada ise \%44,64 ile bilgisayar/tabletler yer almaktadır. Vaka bu veriler dikkate alınarak seçilmiş olup veri toplama aşamasında örneklem seçimi "tesadüfi olmayan örneklem yöntemleri” ile gerçekleştirilmiştir.

Çalışmada erişimi kolay olan ve arzu edilen niteliklere sahip bireylerin belirlenip seçilmesi kıstasları dikkate alınarak yargısal örnekleme tekniği kullanılmıştır. Konu yöntemde vaka konusunda bilgi sahibi olan şahısların seçimi ve araştırma konu ve kapsamına uygunluğu gibi konularda katılımcı belirleme sürecini araştırmayı bırakmaktadır. Bu kapsamda görüşme yapılacak 
şahıslar seçilmiş ve yarı-yapılandırılmış görüşme yöntemi ile yüz yüze mülakat gerçekleştirilmiştir. Görüşmeler kapsamında sorular sorulmuş, gündem kapsama bağlı kalınarak belirlenmiş, gözlem ve dinlemeler yapılmış, detaylı incelemeler sağlanmıştır (Berg, 2001; Keegan, 2009; Mills vd., 2010; Nakip, Yaraş, 2017). Bahse konu koşullar dikkate alınarak Tablo 4'te belirtilen yetkililerle sırası ile görüşülmüştür. Görüşmeler bütüncül kanalın önemli bileşenleri olan pazarlama, e-ticaret ve perakende alanları dikkate alınarak organize edilmiştir. C kodlu departman konuya gösterdikleri ilgi ve duyarlılıktan ötürü çoklu katılım gerçekleştirmiştir. Tablo 4'te görüşülen kişilere ilişkin bilgilere yer verilmiştir.

Tablo 4: Katılımcı Bilgi Listesi

\begin{tabular}{|c|c|c|c|c|}
\hline $\begin{array}{l}\text { Departman } \\
\text { Kodu }\end{array}$ & Görevi & $\begin{array}{l}\text { Sektör } \\
\text { Tecrübesi }\end{array}$ & $\begin{array}{l}\text { Mevcut Firma } \\
\text { Tecrübesi }\end{array}$ & Cinsiyeti \\
\hline $\mathbf{P}$ & $\begin{array}{l}\text { Akıllı Telefon, Mobil ve IOT Cihazlar } \\
\text { Pazarlama ve Ürün Yöneticisi }\end{array}$ & $10 \mathrm{y} 1 \mathrm{l}$ & $6,5 \mathrm{y} 1 \mathrm{l}$ & Erkek \\
\hline $\mathbf{E}$ & E-Ticaret Uzmanı & 4,5 yil & 3,5 y1l & Erkek \\
\hline $\mathbf{M}$ & $\begin{array}{l}\text { Perakende Pazarlama ve Pazarlama } \\
\text { İletişimi (Perakende ve Müşteri Deneyimi } \\
\text { Geliştirme Departmanı) }\end{array}$ & 4,5 yil & $2,5 \mathrm{y} 1 \mathrm{l}$ & Kadın \\
\hline $\mathbf{M}$ & $\begin{array}{l}\text { Perakende Pazarlama ve Pazarlama } \\
\text { İletişimi (Perakende ve Müşteri Deneyimi } \\
\text { Geliştirme Departmanı) }\end{array}$ & $10 \mathrm{y} 1 \mathrm{l}$ & 4 y1l & Kadın \\
\hline
\end{tabular}

\subsection{Araştırma Bulguları}

Elektronik sektöründe 21 yıldır Türkiye'nin ihracat lideri olarak 155 ülkede çeşitli ürünlerle ihracat gerçekleştiren konu firma aynı zamanda Türkiye, İngiltere, Tayvan ve Çin'de toplam 8 ArGe merkezi ile faaliyet göstermektedir. Ayrıca Türkiye'nin ilk yerli tasarımı olan akıllı telefonun da üretici konumundadır.

Çalışma kapsamında araştırmaya konu olan işletmenin bütüncül kanal ile ilişkisi kavrama olan bakış açısı, uyumluluğu, müşterilerin gözünden kavramın niteliği ve müşterilere sağladığı faydalar 
olarak adlandırılan başlıklar altında ele alınmış olup, konu hakkında bilgisi olan ve konuya ilgili şahıslarla görüşmeler gerçekleştirilerek elde edilmiştir.

\section{Bütüncül Kanal Bakış Açısı}

Görüşmelerde bütüncül kanalın müşteri beklentileri çerçevesinde ne denli önemli bulunduğunun anlaşıldığ1, müşterilere verilecek hizmetin niteliğinin konu uygulama ile ne düzeye çıkartılacağının anlaşıldığı ve kavramın pazara sunulacak ürün ya da hizmet için önemli bir katma değer olarak algılandığı gözlenmektedir. Görüşmelerde konuya ilişkin bakış açısı şu şekilde ifade edilmiştir:

“... artık o kadar yoğun bir zamandayız ki insanlar alacakları bir ürünü, bir hizmeti en pratik, en hizlı ve araştırarak en basit şekilde her noktada, her zaman, rahat bir şekilde bulmak istiyorlar. Böyle bir dünyada da bütüncül kanal çok önem kazanıyor çünkü siz istediğiniz kadar üründe rekabetçi olun, çok iyi pazarlama yapın, en iyi yöntemlere başvurun, bütüncül kanala entegrasyon yoksa artık ayakta kalmak çok çok zor..." (P Departmanı)

“...bir tercih değil zorunluluk diye düşünüyoruz çünkü \%25'e yakın oranlarda online satın alıp, măgazadan teslim alma durumları ortaya çıktı. Tüketiciler artık hız istiyor... Artık bu tüketici için bir tercih olacak. Bir haftada gönderen firmalardansa belki bir gün içerisinde belki 1 saatte gönderen firmaları tercih edeceğini düşünüyoruz. Biz de bu doğrultuda yatırımlarımızı şekillendirmeye çalışıyoruz..." (E Departmanı)

"Zaten bizim 1,5-2 senedir gündemimizde olan ve bu sene de ciddi anlamda üzerinde çalıştığımız bir konu... Sürekli online olan, sürekli online alışveriş yapan, artık online alışveriş yapmayı fizikselin de önüne koymuş bir kitle için bu durum artık olmazsa olmaz. Şu anda bizim sektörde bu çok fazla yaygın bir durum değil. Ama zaman içerisinde bunu ilk yapan firma olacak olmak çok keyifli bir şey olacak diye tahmin ediyorum çünkü herkesin beklentisi bu yönde... bir noktada ona yetişmek gerekiyor diye düşünüyorum.” (M Departmanı) 


\section{Bütüncül Kanala Uyumluluk}

Bütüncül kanalın görüşmelerin gerçekleştirildiği işletme ve işletmenin bulunduğu sektör tarafından önem düzeyi bilinmekte olup, farkındalık seviyesi yüksek olsa da bu durum kavramın hali hazırda teorik çerçeveden çıkabildiği sonucunu ortaya çıkartmamaktadır. Kavram yalnızca teorik bilinç temelinde var olup, uygulama alanında kendine yer bulamamıştır. Mobil cihazlar pazarında da görüşmelerden elde edilen bilgilere göre bütüncül kanal entegrasyonunun henüz var olmadığı, yalnızca e-ticarette stok ve tüketim yoğunluğunun tekstil gibi daha çok olduğu alanlarda bütüncül kanalın var olduğu belirtilmektedir. Bütüncül kanala uyumluluk ise şu şekilde ifade edilmiştir:

“Türkiye'deki evre biraz daha çoklu kanal seviyesi...Türkiye'de çoklu kanalda takılıp kalmış olmamız bir problem. Giyim sektörü bu anlamda çok başarılı diyebilirim. Bu açıdan baktığımızda Türkiye'de bütüncül kanala en hazır sektör hazır giyim sektörüdür. Peki mobil tarafta nasıl derseniz? Buy-Back programlarl var ... ama bu \%100 bütüncül olduğu anlamına gelmiyor... Mobil cihazlar pazarında küçük örnekler var ama tam bir entegrasyon yok." (P Departmani)

“Tüketici isteğini karşılamak çok önemli. Zaten burada da tüketici bütüncül kanal olayında her yerde destek istiyor. Mobil cihazlar ya da küçük ev aletleri cihazlar bütüncül kanal kurgularına daha uygun. Internet üzerinden alımlarda da genellikle sepet büyüklüğü küçük ürünler daha çok tercih ediliyor. Bu yüzden mobil cihazlar da bütüncül kanal kuygularında daha önemli bir yere sahip... Bizim satın alma ve ziyaret sayllarımı aslında \%70 mobil cihazlar üzerinden gerçekleşiyor. Bu da mobil cihazlar pazarının ticarette ne kadar hakim olmaya başladı̆̆ını gösteriyor. Bütüncül kanal da mobil cihazlar kesinlikle olmazsa olmaz diye düşünüyorum." (E Departmanı)

“Bizim geçmişten gelen, ciddi anlamda bütüncül kanala uygun olmayan bir altyapımız var. Silolaşma çok fazla. Müşteri hizmetlerinin topladı̆̆ı ayrı bir veri var, bayi kanalından gelen ayrı bir veri var, e-ticaretten gelen ayrı bir veri var. Ve bunlar da henüz birbiriyle konuşmuyor. Bütün kanalları konuşturabilmemiz bütüncül kanalın merkezinde olduğu için maalesef şu an bütüncül kanal deneyimi sunuyoruz diyemeyiz ama bu konuya ciddi anlamda önem verdiğimiz 
için bütün altyapımızı buna adapte etmeye çalışıyoruz... Dijital ekran projemiz var... Fiziksel mă̆azada da çevrimiçiymiş gibi davranabileceği bir mă̆aza sistemi yaratmaya çalışıoruz. Direkt bütüncül kanala entegreyiz demek için çok erken ama dijitalle fiziksel mă̆azayı nasıl iç içe geçiririzin başladığı bir dönemdeyiz." (M Departmanı)

\section{Müşterilerin Bütüncül Kanala Bakış Açısı}

Görüşmelerden elde edilen bilgilere göre müşteriler iletişim kanalı olarak kavramın ne olduğu tam olarak bilmeseler dahi bütüncül kanala karşı isteklilik düzeyleri yüksek olarak ifade edilmektedir. Görüşmelerde daha önceki çalışmalarda elde edilen sonuçlara (Peltola vd., 2015) benzer şekilde müşterilerin kanallar arası geçişi talep ettikleri gözlenmektedir. Ayrıca yapılan araştırmalara atıf yapılarak bilgi paylaşımı yapıldığı ve çevrimiçi ile fiziksel ortamın müşteriler tarafından bir şekilde içiçe şekilde kullanıldığı anlaşılmaktadır. Bu durum müşterilerin bütüncül kanalı kullandığı, kullanmaya çalıştığı, istekli olduğu ya da ihtiyaç duyduğu bir yaklaşım olarak algılanmasına vesile olmaktadır. Bununla birlikte günümüz itibarıyla müşteriler için çoklu kanalın yeterli düzeyde doyurucu olmadığı bütüncül kanal entegrasyonu arttıkça müşteri-işletme bağlılığının olumlu şekilde tetiklendiği belirtilmektedir. Konuya ilişkin görüşler şu şekilde ifade edilmektedir:

”...müşterilerin \%50'si mağazaya gitmeden önce ürün hakkında bilgi sahibi olmak istiyor... Türkiye'de “ürünü nereden alabilirim?” bilgisini araştırma geçen seneye göre \%200 artmış. "Bana en yakın mă̆azanın konumu nerede?” araştırması ise \%250 artmış. Bu açıdan baktığımızda bütüncül kanalı isim olarak bilmeselerde ciddi bir talep var. Aslında bunu talep ettikleri için kavram buraya geliyor da diyebiliriz ama Türkiye'de tam anlamı ile bütüncül bir sunum olmadığ için müşterilerin talebinde bir sektör sıralaması yapamıyoruz. Fakat gördüğ̈̈müz kadarlyla ürün-sektör farketmeksizin müşterinin talebi olduğunu anlayabiliyoruz." (P Departmanı)

Müşterilerin aslında istediği şeyler çok basit. Tüketici anında ulaşmak istiyor. Hızlı ve rahat bir şekilde nerde olursa olsun alımı yapmak istiyor. Ben ürünümü aldım bir günde bana gelsin de ister depodan ister bayi üzerinden gelsin, yeter ki gelsin. Örnek olarak bir-iki gün sonra 
derbi maçı var ve dev bir TV alacak maçı izlemek için. Normalde o ürün hemen yetişmeyecek. Bütüncül kanal kurgusu ile bu durum mümkün oluyor. Tüketici bunu istiyor.” (E Departmanı) "Müşteri beklentileri kitlenin yaşadlğı yere, kuşağına göre çok değişen bir durum ama şehirde yaşayan $Z$ ve $Y$ kuşaklarını düşündügümüzde zaman tasarrufu ve hız isteniyor." (M Departmani)

\section{Bütüncül Kanal Faydaları}

Yapılan görüşmelerden elde edilen bilgilere göre bütüncül kanal entegrasyonunun asgari seviyede olduğu mevcut koşullarda dahi müşterilere fayda sağlandığı ama tam entegrasyonla birlikte birleşen data altyapısının müşterilere daha kapsamlı faydalar sağlayacağı ifade edilmektedir. $\mathrm{Bu}$ noktada mobil cihazlar pazarında akıllı cep telefonlarının bayrak taşıyan pozisyonda konumlanabileceği, hem kendi ürün gamı açısından hem de diğer pazarlarla olan bağlantısı açısından kapsayıcı bir konumda olduğu ifade edilmektedir. Bir başka deyişle bütüncül kanaldan faydalanan ve bütüncül kanalı yaratan temel öge olarak değerlendirilmektedir.

Bütüncül kanalın sağladığı faydalar dikkate alındığında mobil cihazların hem kendi pazarını tetikleyen hem de diğer sektörlerde müşteri ve işletme faydalarını artıran bir yapıda tanımlanması mobil cihazları daha farklı bir konuma yerleştirmektedir. Bu yapı itibarı ile mobil cihazlara ilişkin bütüncül kanal faydaları değerlendirildiği diğer pazarların faydalarından da pay alabileceği varsayılmaktadır. Bütüncül kanalın mobil cihazlar pazarında müşteriye sağladığı faydalar Tablo 4'te belirtilmektedir. Konuya ilişkin görüşler ise şu şekilde ifade edilmiş̧ir:

“...müşsteriler daha iyi anlaşıldığı için alacağınız ürünün kişiselleştirilmesi sağlanacak. Her kanalda müşterinizi ortaklaştırabiliyorsunuz. Mağazaya gidip bir ürün aldığınızda datanız oluştu, onlineda aldiğınızda datanız oluştu, bunları birleştiremediğinizde farkl fiyat ve hizmet sunabiliyorsunuz ama dataları birleştirirseniz müşterileri anlayabiliyorsunuz... Bütüncül kanal olmadığında ürünü almak için doğru kanala gitmeniz lazım ama bütüncül kanalda zaten istediğiniz anda ürünü alabiliyorsunuz... En büyük faydası müşteri artık firmaya göre hareket etmiyor, firma müşsteriye göre hareket ediyor... Bu noktada Mobil cihazın bir artısı var diğer ürünlere göre. Bütüncül kanalı müşterinin gözünde önemli hale getiren mobil cihazın kendisi, en çok da cер telefonu. Cер telefonu üzerinden e-ticaret yapıllyor, mağazalar aratıllyor, satın 
alınacak yer aratıllyor, ürünün özelliği aratıllyor. Yani hem mobil cihaz bu işin merkezinde hem de cep telefonu en önemli noktada. Başrolde olan oyuncu akıllı cihazlar-cep telefonları çünkü diğer pazarlarla da bă̆lantı sağlıyor. " (P Departmanı)

"Bu faydaları ikiye ayırabiliriz. Bir tanesi tüketici için hız ve anında erişim gibi faydalar. Firma açısından da operasyonel, stok seviyesi, lojistik maliyeti açısından faydası var. Böyle olunca mağazadan alan kişilere daha ucuza ürün verme yapılabilir çünkü lojistik maliyetten kazanç sağlanıyor. Bu da tüketiciye fiyat, hız ve erişim faydası sağllyor. Ayrıca stok bilgisi ile birlikte internetten bakıp anında mağazadan hem satın alma hem teslim alma işlemi gerçekleştirebilecek bir fayda söz konusu... Dijitaldeki müşteriyi mağazaya yönlendirme, mağazadaki müşteriyi dijitale çekme gibi faydalar da sağlıyor.” (E Departmanı)

"Müşteri açısından bu durum büyük bir kolaylık. Hem zamandan tasarruf edebiliyorsun hem etrafındaki çok fazla satış noktası, satış kanalını düşündüğ̈̈nde tek bir tane güvenilir bir kanalla ilerleme tercih sebebi olabiliyor... En büyük sebep bence kolaylık ve güven diye düşünüyorum... Mobil cihazlar klyafet gibi olmadığu için biraz daha araştırma gerektiren, karşılaştırma gerektiren bir süreç. Ama bunu belki fiziksel yoldan yapmayıp online yoldan yapmak hem zamandan hem de aslında bu ürünü satın almaya karar verdiği noktada tüketiciye pahada ve fiziksel yük olarak fayda sağllyor. Satın alma, kurulum, satış sonrası hizmet gibi tüm işlemleri dijital yollarla halledip büyük bir kolaylık sağllyor.” (M Departmanı) 
Tablo 4: Bütüncül Kanalın Müşteri Faydaları

\begin{tabular}{|c|}
\hline Mobil cihazların diğer pazarlar için sunduğu bütüncül fayda \\
\hline Müşterinin firmaya göre değil, firmanın müşteriye göre davranması \\
\hline Müşterinin zaman, mekân, tercih faydası \\
\hline Kanallar arası risk algısının azalması faydası \\
\hline Farklı kanal işlemlerine farklı kanallarda çözüm faydası \\
\hline Firma-müşteri ilişkisinde ortaklaşabilme faydası \\
\hline Kişisel ürün ve hizmet geliştirme faydası \\
\hline Fiyatlandırma ve promosyon faydası \\
\hline Müşterinin tutum ve davranışına göre interaktif işletme davranışı faydası \\
\hline Stok, konum, fiyat vb. bilgilendirmede anlık/gerçek zamanlılık faydası \\
\hline Fiziksel-Çevrimiçi kanallarda eş zamanlı olarak alternatif iletişim faydası \\
\hline İnceleme, sipariş, satın alma, teslimde çoklu tercih faydası
\end{tabular}

\section{Sonuç ve Öneriler}

Günümüzde tüketiciler artan gelir seviyesi, hızla değişen tüketim alışkanlıkları, satın alım coğrafyasının gelişmesi ve genişlemesi, rekabetin artması, alternatif ürün bilgisinin kolay temini ve hızlı tüketen toplum yapısına evrilmesi gibi değişimlerle birlikte hemen her konuda taleplerine daha hızlı geri bildirim alabildikleri durumları tercih etme eğilimindedirler. Bütüncül kanal yaklaşımı ise bu gibi ihtiyaçların karşılanması hususunda müşterilere bulundukları ortamdan bağımsız sonsuz ürün çeşitliliği, birçok fiyat alternatifi ve farklı teslim seçenekleri sunan bir yap1 yaratmaktadır. Bununla birlikte tıpkı müşterilerin işletmeleri ve markaları bildiği gibi, işletmelerde müşterilerini tekli bir satın alma itibarı ile değil, uzun dönem davranış bütünlüğü çerçevesinde tanıyarak ona yaklaşacaktır. Bu durum işletmelere çeşitli zorluklar getireceği gibi (Kazançoğlu vd., 2017) müşterin de birçok açıdan fayda sağlamasına firsat yaratmaktadır.

Türkiye'de e-ticaretin günden güne artan bir ticari faaliyet olduğu dikkate alındığında ve e-ticaret alanında hazır giyim, elektronik ve gıda ürünlerinin başı çektiği düşünüldügüunde (Dicle vd., 2019) Türkiye'de elektronik pazarda önemli aktörlerden olan firmanın bütüncül kanal yaklaşımına daha erken entegre olması beklenmektedir. Bununla birlikte mobil cihazların kendi ürün grubu dışında kalan diğer tüm pazarlara da bütüncül kanal açısından fayda sağladığı düşünüldüğünde, kavramı 
yaratan aktörlerden biri olarak kendi pazarında uygulamanın eksik kalması pazarın zayıflı̆̆ı olarak değerlendirilebilmektedir. Bu noktada e-ticarette bu denli yüksek bir hacme sahip olmasının kendi ürün grubunda yaratılmış olan bütüncül kanal yaklaşımı ile değil, diğer ürün gruplarında bütüncül kanalı tesis eden temel ürün olması ile ilgili olabileceği de varsayılmaktadır. Ayrıca teknolojik bilgi birikimi ve Ar-Ge gibi konularda yapılan yatırımlar dikkate alındığında günün koşullarına ayak uyduracak bir entegrasyonun beklendiği de değerlendirilebilmektedir.

Ayrıca bulgulanan faydalar dikkate alındığında müşterilerin fiziksel kanaldan erişemediği ürünlere erişim faydası (Giddes vd., 2014), marka bilinirliğini artırarak müşterinin satın alma adımlarındaki risk algısını azaltması (Cao, Li, 2015; Shi vd., 2020), çoklu ürün faydasından ötürü ürün çeşitlilik ve türetim çokluğu faydası (Sopadjieva vd., 2017; Bell vd., 2017), sipariş, satın alma, teslim ve iade çeşitliliği ve kolaylığı faydası (Zhang, Shi, 2018) gibi faydaların konu çalışmanın çıktıları ile örtüştüğü fakat bununla birlikte işletmenin henüz tam entegrasyon sağlamamış olmasından ötürü konu faydaların en üst düzeyde sunulamadığı da anlaşılmaktadır. Buna göre bilinen faydaların devreye sokulmasının hem müşterilere hem de işletmelere kazan-kazan faydası da yaratacağı ön görülmektedir.

Bütüncül kanalın müşterilere sunduğu tek bir müşteri olma, müşteriye göre hareket etme, her kanalda aynı görünme vb. gibi faydalar dikkate alındığında da mobil cihaz pazarında bu gibi faydaların müşterilere halihazırda sunulamıyor olması, veri altyapısının henüz bütünleştirilememiş olması mobil cihazların diğer ürün gruplarına sunduğu imkan ve faydaları kendi ürün grubunda yaratamadığı olarak değerlendirilebilmektedir. Ayrıca firmanın menşei ülkesinde özellikle cep telefonlarının çok sık tüketime konu olan bir ürün olduğu, mevcut telefonların \%58'inin son iki yıl içerisinde alındığı, satın alınan kanalın ise \%54 oranında fiziksel mağaza, \%21 oranında ise çevrimiçi ortamlar olduğu (DeLoitte, 2019) dikkate alındığında konu pazarın müssterilerini daha iyi tanıması, datalarını eksiksiz şekilde bütünleştirmesi, davranışlarını ve tüketim alışkanlıklarını takip ederek kanallar arasında entegrasyonu yaratması hem işletme hem de müşterileri açısından önemli olarak nitelendirilebilecektir.

Çalışmanın keşif amaçlı bir çalışma olduğı da ve evrenin tamamını ifade etmediği dikkate alınmalıdır. Buna göre takip eden çalışmalarda kapsamın genişletilerek daha geniş bir örneklem üzerinden ele alınabileceği, karşılaştırmalı bir çalışma yapılabileceği ve nitel olarak 
gerçekleştirilen çalışmadan elde edilen bulgular 1şığında nicel bir çalışma yapılması da düşünülebilir.

\section{Kaynakça}

AYDIN, H., KAZANÇOĞLU, İ. (2017). Çoklu Kanal Stratejisinden Bütüncül Kanal Stratejisine Geçişin Tüketiciler Tarafından Kabulü. Mustafa Kemal Üniversitesi Sosyal Bilimler Enstitüsü Dergisi, 57-77.

BARWITZ, N., MAAS, P. (2018). Understanding the Omnichannel Customer Journey:

Determinants of Interaction Choice. Journal of Interactive Marketing, 43, 116-133.

BECK, N., RYGL, D. (2015). Categorization Of Multiple Channel Retailing In Multi-, Cross-, And Omni-Channel Retailing For Retailers And Retailing. Journal of Retailing and Consumer Services , 170-178.

BELL, D.R., GALLINO, S., MORENO, A. (2017). Offline Showrooms in Omni-channel Retail: Demand and Operational Benefits. Management Science, 64 (4), 1629-1651.

BERG, B. L. (2001). Qualitative Research Methods For Social Scientists. Boston: Allyn \& Bacon.

BERMAN, B., THELEN, S. (2018). Planning And Implementing An Effective Omnichannel Marketing Program. International Journal of Retail \& Distribution Management, 46 (7), 598614.

CAO, L., LI, L. (2015). The impact of cross-channel integration on retailer's sales growth. Journal of Retailing, 91 (2), 198-216.

CHEVALIER, S. (2021). Retail e-commerce sales worldwide from 2014 to 2024. https://www.statista.com/statistics/379046/worldwide-retail-e-commerce-sales/ adresinden ulaşı1dı (21.08.2021). 
DELOITTE. (2017). Dijitalleşen Hayatımızda Mobil Teknolojilerin Yeri Deloitte Global Mobil Kullanıcı Anketi 2017: Türkiye Yönetici Özeti. İstanbul, Türkiye: DeLoitte.

DELOITTE. (2019). Hayatımızın Merkezindeki Mobil Teknolojiler, Deloitte Global Mobil Kullanıcı Anketi 2019: Türkiye Yönetici Özeti. İstanbul, Türkiye: DeLoitte.

DICLE, E., AVCI, Y. E., UZUNOSMAN, M. (Ed.). (2017). Dijitalleşen Dünyada Ekonominin Itici Gücü: E-Ticaret. (TÜSİAD ve BCG) İstanbul, Türkiye.

DICLE, E., AVCI, Y.E., GÜLYURT, L. (Ed.). (2019). E-Ticaretin Gelişimi, Sınırların Aşılması ve Yeni Normlar 2019. (DeLoitte Digital ve TÜSİAD), Türkiye.

GIDDES, I., WILLIAMS, C., GUTHMANN, T. (Ed.) (2014), The omnichannel opportunity: unlocking the power of the connected consumer, https://www2.deloitte.com/content/dam/Deloitte/uk/Documents/consumer-business/unlockingthe-power-of-the-connected-consumer.pdf adresinden ulaşıldı (03.01.2020).

HÜBNER, A., WOLLENBURG, J., HOLZAPFEL, A. (2016). Retail Logistics In The Transition From Multi-Channel To Omni-Channel. International Journal of Physical Distribution \& Logistics Management, 562-583.

HÜSEYINOĞLU, I. Ö. (2017). Bütüncül Kanal (Omni-Channel) Stratejisinin Incelenmesi: Gıda Perakendecisinden Bulgular. Dumlupınar Üniversitesi Sosyal Bilimler Dergisi , 119-133.

International Telecommunication Union Publications. (2019). Measuring Digital Development Facts and Figures 2019. İsviçre: Cenevre.

KANG, J. M. (2018). Showrooming, Webrooming, and User-Generated Content Creation in the Omnichannel Era. Journal of Internet Commerce , 145-169.

KAZANÇOĞLU, İ., VENTURA, K., AKTEPE, Ç. (2017). Perakendecilikte Omni-Kanal Uygulamaları: Lojistik Faaliyetlere Ilişkin Zorluklar Ve Engeller. International Journal of Economic and Administrative Studies , 219-236. 
KEEGAN, S. F. (2009). Qualitative Research Good Decision Making Through Understanding People, Cultures And Markets.Londra: Kogan Page Publishing.

KOTLER, P., KARTAJAYA, H., SETIAWAN, I. (2018). Pazarlama 4.0 Gelenekselden Dijitale Geçiş. İstanbul: Optimist Kitap.

KUYUCU, M. (2017). Gençlerde Akıllı Telefon Kullanımı ve Akıllı Telefon Bağımlılığı Sorunsalı: "Akı1lı Telefon (Kolik)" Üniversite Gençliği. Global Media Journal TR Edition, 7(14), 328-359.

MILLS, A. J., DUREPOS, G., WIEBE, E. (2010). Encyclopedia Of Case Study Research (Vol. 1). Londra: Sage Publications.

NAKİ, M., YARAŞ, E. (2017). SPSS Uygulamalı Pazarlamada Araştırma Teknikleri (4. Baskı). Ankara: SeçkinYayıncılık.

PELTOLA, S., VAINIO, H., NIEMINEN, M. (2015). Key Factors in Developing Omnichannel Customer Experience with Finnish Retailers. Fui-Hoon, N. F., Tan, C.H. (ed.). HCI in Business. HCIB 2015. Lecture Notes in Computer Science içinde (335-346) Springer: Cham.

PICEK, R., PERAS, D. VE MEKOVEC, R. (2018). Opportunities and challenges of applying omnichannel approach to contact center, 4th International Conference on Information Management (ICIM).

PUNCH, K. F. (2014). Sosyal Araştırmalara Giriş, Nitel ve Nicel Yaklaşımlar (Çev. Bayrak, D., Arslan, H.B., Akyüz, Z.). Ankara: Siyasal Kitabevi.

RITCHIE, J., LEWIS, J. (2003). Qualitative Research Practice: A Guide For Social Science Students And Researchers.Londra: Sage Publications.

SHI, S., WANG, Y., CHEN, X., ZHANG, Q. (2020). Conceptualization Of Omnichannel Customer Experience And Its Impact On Shopping Intention: A Mixed-Method Approach. International Journal of Information Management, 50, 325-336. 
SOPADJIEVA, E., DHOLAKIA, U.P., BENJAMIN, B. (2017). A Study Of 46,000 Shoppers

Shows That Omni-channel Retailing Works, Harvard Business Review, https://hbr.org/2017/01/a-

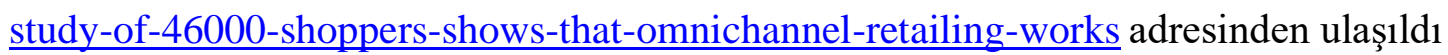
(03.01.2020).

SUNDET, V.S. (2007). The Dream of Mobile Media. Storsul, T., Stuedahl, D. (Ed.). Ambivalence Towards Convergence. Digitalization and Media Change içinde (87-113). Publisher: Nordicom.

TDK. (2019). 25 Aralık 2019 tarihinde https://sozluk.gov.tr/?kelime=MOB\%C4\%B0L adresinden erişildi.

Ticaret Bakanlığı. (2021). https://www.eticaret.gov.tr/istatistikler adresinden ulaşıldı (25.08.2021).

VERHOEF, P. C., KANNAN, P. K., INMAN, J. J. (2015). From Multi-Channel Retailing To Omni-Channel Retailing Introduction To The Special Issue On Multi-Channel Retailing. Journal of Retailing , 174-181.

WOLLENBURG, J., HOLZAPFEL, A., HÜBNER, A.H. (2019). Omni-channel customer management processes in retail: An exploratory study on fulfillment-related options. Logistics Research, 12, 7, 1-15.

YIN, R. K. (2002). Case StudyResearch (Design AndMethods). California: SagePublication.

ZHANG, C. SHİ, X. (2018). Does Omnichannel Selling with Pre-Order and Returns Benefit Consumers?. 15th International Conference on Service Systemsand Service Management (ICSSSM), 1-6.

ZENNER, R., (T.Y.). Advantages Of A Customer-Focused Omnichannel Strategy. (Commercetools) https://ok.commercetools.com/omnichannel adresinden ulaşıldı (03.01.2020). 